\title{
Inhibition of Serum Lipase as a Mechanism of Action for Anti-Obesity Potentials of Dioscorea bulbifera Extracts on Wistar Rats
}

\author{
Precious Whiskey Ikete ${ }^{\circledR}$, Bruno Chukwuemeka Chinko*(]
}

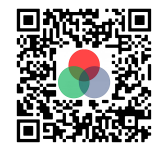

Use your smartphone to scan this QR code and download this article

\begin{abstract}
Objectives: Dioscorea bulbifera possesses profound therapeutic potential and is commonly used in traditional Indian, African and Chinese medicine. The present study aimed to evaluate the effect of a hydromethanolic extract of Dioscorea bulbifera on the serum lipid profile, lipase, ghrelin, food intake and body weight of high-fat obese Wistar rats. Methods: Thirty (30) male Wistar rats weighing 200 - $250 \mathrm{~g}$ were used for the study. Obesity was induced using a formulated high-fat diet for six (6) weeks. They were divided into six (6) groups of five (5) rats each. The negative control received distilled water, while the positive control received a standard antihyperlipidemic drug, simvastatin Obese rats were treated with hydromethanolic extract of Dioscorea bulbifera at $200 \mathrm{mg} / \mathrm{kg}$ and 400 $\mathrm{mg} / \mathrm{kg}$ for a period of two (2) weeks. Results: The results showed significantly decreased serum total cholesterol (TC), low-density lipoprotein (LDL), lipase, fasting blood glucose and body weight of experimental animals compared to the negative control $(P<0.05)$, while serum high-density lipoprotein (HDL) and ghrelin were found to be significantly higher in experimental animals compared to the negative control $(p<0.05)$. There was no significant change in the food intake of the animals. Conclusion: The antiobesity potentials of hydromethanolic extracts of Dioscorea bulbifera may be attributable to their ability to reduce lipase activity while attenuating the lipid profile in high-fat obese Wistar rat models. Therefore, this study considers Dioscorea bulbifera as a potential natural anti-obesity agent with possible anti-lipase activity.

Key words: Dioscorea bulbifera, high-fat diet, obesity, ghrelin, lipase, body weight
\end{abstract}

\section{INTRODUCTION}

Obesity refers to the excessive accumulation of body adipose tissue with a tendency to impair health. It is a chronic, stigmatized and costly metabolic disease that is rarely curable with increasing prevalence throughout the world according to the World Health Organization Fact Sheet ${ }^{1,2}$. Obesity results from energy imbalance from high-energy diets, sedentary lifestyles and genetic make-up ${ }^{3,4}$. With its associated comorbidities, such as type-2 diabetes, hypertension and other cardiovascular diseases (CVDs), osteoarthritis and some cancers, it has been reported as a leading risk for deaths globally, accounting for up to 2.8 million deaths annually ${ }^{2,4}$.

Long-term management and prevention for obesity involve lifestyle modifications in the form of dieting and exercise with pharmacological and surgical interventions required in extreme cases to achieve significant weight loss ${ }^{5,6}$. Surgical procedures for weight loss are geared toward reducing the size of the stomach or bypassing a portion of the intestines to limit the quantity of food consumed. On the other hand, drugs used for weight loss work by inhibiting gastric lipases or by reducing appetite ${ }^{7,8}$. While gastrointestinal surgeries are fraught with lifetime complications, the chronic use of drugs is associated with severe adverse side effects ${ }^{9}$. Safety concerns have remained the principal reason for the withdrawal of anti-obesity drugs ${ }^{10}$. This has continued to fuel research on the use of natural phyto-pharmacological agents in the treatment and management of obesity with little or no side effects. A variety of natural plant materials in the form of fruits, vegetables and herbs have been evaluated for their anti-obesity potentials and are currently being promoted in the development of nature-based anti-obesity agents ${ }^{11,12}$. These plant materials have been shown to exert this function by enhancing thermogenesis, inhibiting lipase activity, preventing adipocyte differentiation, enhancing lipid metabolism and suppressing appetite ${ }^{11-14}$.

Dioscorea bulbifera remains one of the widely used yam varieties in Africa and Asia, where they are mostly used for several medicinal purposes. It belongs to the Dioscoreaceae family and is commonly known as air potato or aerial, bitter yam or cheeky

access article distributed under the terms of the Creative Commons Attribution 4.0 International license. 
yam ${ }^{15,16}$. The bulbils have a characteristic faint odor and a bitter state, which makes them less desirable than other yam species for food. However, it has been noted as the yam species with the highest amount of protein, zinc, sodium, calcium and magnesium as well as vitamins $\mathrm{B} 1, \mathrm{~B} 3$ and $\mathrm{C}^{17}$. The bulbils, tubers and leaves of the plant have a wide range of applications in folk remedies and have been used in the treatment of various ailments, such as piles, dysentery, syphilis, ulcers, leprosy and dysentery and tuberculosis ${ }^{18,19}$. It is also used as a contraceptive and as an aphrodisiac ${ }^{20}$. Documented studies have reported its antioxidant, anti-diabetic, hematinic, anti-hyperlipidemic, analgesic and antiinflammatory properties ${ }^{21-28}$. Although extracts of Dioscorea bulbifera have been shown to reduce body weight in normolipidemic and hyperlipidemic rat models, the mechanism of action has yet to be evaluated $^{22,28,29}$.

The present study aims to study the effect of extracts of Dioscorea bulbifera on serum lipase and ghrelin as well as food intake using Wistar rat models as a possible mechanism of action for its anti-obesity activity.

\section{METHODS}

\section{Collection and Preparation of Plant Mate- rial}

Bulbils of Dioscorea bulbifera were freshly harvested from Odume Farm (Enugu State, Nigeria). They were correctly identified and authenticated by a plant biologist at the Plant Science and Biotechnology Department of the University of Port Harcourt, herbarium Number (UPH/C/132). They were thoroughly washed in running water, cut into tiny pieces and shed dried for two weeks. The dried plants were ground with an electrical blender and were ready for extraction.

\section{Plant Extraction and Phytochemical Screening}

Dried, ground plant material (1 kg) was mixed with $80 \%$ methanol and stored at $37^{\circ} \mathrm{C}$ for 24 hours in a shaking incubator at $160 \mathrm{rpm}$. The mixture of plant material in methanol was centrifuged for 15 minutes at $5000 \mathrm{rpm}$. The supernatant solution was stored separately, while the infranatant mixture was subjected to another round of mixing with $80 \%$ methanol followed by centrifugation, and the resulting supernatant was stored. These processes were repeated three times. All the supernatants were mixed and filtered using a vacuum filter. The filtrate was then concentrated under reduced pressure in a rotary evaporator. The resultant extract was lyophilized to dryness and stored at $2^{\circ} \mathrm{C}$ before and throughout the experiment. Phytochemical screening was performed using standard methods $^{30}$.

\section{Experimental Animals}

Thirty (30) male Wistar rats weighing $200-250 \mathrm{~g}$ were used for the study. They were inbred from the Animal House of the Department of Human Physiology, University of Port Harcourt. They were housed under standard animal husbandry conditions: wellventilated rat cages, room temperature $\left(25 \pm 0.50^{\circ} \mathrm{C}\right)$, natural day/light cycle and allowed standard rat chow (Top Feed LTD., Sapele, Nigeria) and clean drinking water ad libitum. The animals were acclimatized for 2 weeks before the start of the experiment.

\section{Induction of Obesity}

Obesity was induced naturally using a formulated high-fat diet. All the experimental animals were allowed a mixture of standard rat chow (80\%) and rendered cow fat (20\%) ad libitum for a period of six (6) weeks. The body weight of the animals was measured, and rats with up to a $35 \%$ weight increase were considered obese and used for the study.

\section{Experimental Design}

Thirty (30) obese male Wistar rats were randomly assigned to 6 groups of 5 animals and treated as follows. Group 1 - Negative Control (water)

Group 2 - Positive Control (Simvastatin 10 mg/kg)

Group 3 - 200 mg/kg Dioscorea bulbifera

Group 4- 400 mg/kg Dioscorea bulbifera

Group 5-200 mg/kg Dioscorea bulbifera + High-fat diet

Group 6 - 400 mg/kg Dioscorea bulbifera + High-fat diet

Groups 1 and 2 served as the negative and positive controls, respectively, while groups 3 to 6 served as the experimental groups. While the high-fat diet was discontinued for groups 1, 2, 3 and 4, it was continued for groups 5 and 6 . Oral treatment of the animals with hydromethanolic extracts of Dioscorea bulbifera lasted for two (2) weeks.

\section{Measurement of Food Intake}

Throughout the experiment, the animals were allowed a measured quantity of rat chow ad libitum. The quantity of food left after 24 hours of feeding was collected and weighed to determine food intake. 


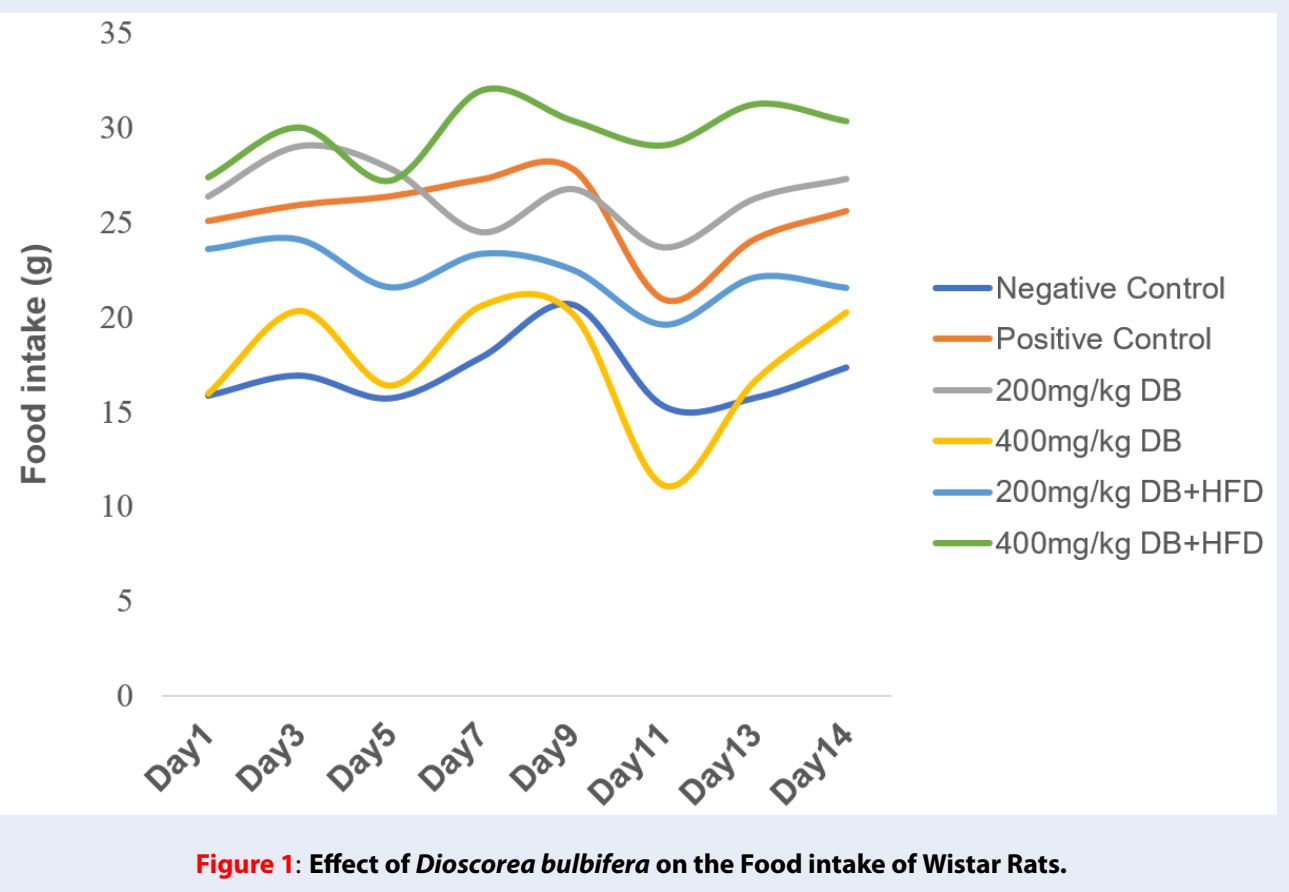

\section{Blood Sample Collection and Assay}

Following overnight fasting, animals were anesthetized by cervical dislocation, and $3 \mathrm{ml}$ of blood was collected via cardiac puncture into a dry sample bottle. Blood was centrifuged for 5 minutes at 3000 rpm, and supernatant serum was collected for laboratory assays. Serum total cholesterol (TC), highdensity lipoproteins (HDL), low-density lipoproteins (LDL), and lipase were analyzed using spectrophotometric methods (Randox, UK), serum ghrelin was analyzed by ELISA (Elabscience, China), and fasting blood glucose was measured using a standard glucometer (Accu-Chek, UK).

\section{Statistical Analysis}

The statistical analysis was performed using IBM Statistical Package for Social Science (SPSS) version 20. The mean and standard error of the mean were calculated for each group of animals. The difference among the groups was determined using one-way analysis of variance (ANOVA) followed by Fisher's least significant difference (LDS) post hoc analysis. A p value of less than 0.05 was considered statistically significant.

\section{Ethical Consideration}

This study was carried out in line with the highest ethical standard in line with guidelines from the Nigerian Institute for Medical Research. The study design was approved by the University of Port Harcourt Research Ethics Committee UPH/CERAMAD/REC/MM76/018.

\section{RESULTS}

Preliminary phytochemical screening of the hydromethanolic extract of Dioscorea bulbifera is shown in Table 1. The results indicate the presence of significant quantities of alkaloids, flavonoids, tannins, saponins, cardiac glycosides, terpenes and carbohydrates.

The effect of Dioscorea bulbifera extracts on the serum lipid profile, ghrelin and fasting blood sugar of highfat induced obese Wistar rats is shown in Table 2. The results show a significant decrease in the mean values of TC, LDL, lipase, and fasting blood sugar among the rats treated with Dioscorea bulbifera compared to the negative control $(\mathrm{p}<0.05)$. Similarly, the mean values of TC, HDL, LDL, lipase and fasting blood sugar significantly decreased compared with the positive control $(\mathrm{p}<0.05)$. Additionally, the mean values of HDL and ghrelin were found to increase in the experimental groups compared to the negative control $(\mathrm{p}<0.05)$, with a similar significant increase obtained for serum ghrelin in the experimental groups when compared with the positive control $(\mathrm{p}<0.05)$.

The effect of Dioscorea bulbifera extract on body weight changes in high-fat induced obese Wistar rats is shown in Table 3. The result indicates that there was a significant reduction in body weight of the experimental animals compared to the negative control 


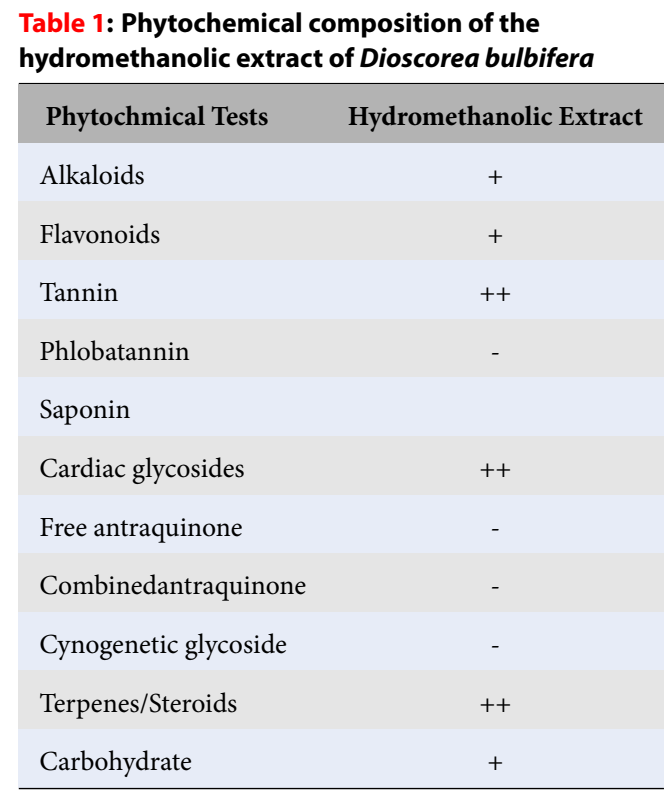

Table 2: Effect of Dioscorea bulbifera extract on the lipid profile, lipase, ghrelin and fasting blood sugar of Wistar rats

\begin{tabular}{|c|c|c|c|c|c|c|}
\hline Groups & $\begin{array}{l}\text { TC } \\
(\mathrm{mg} / \mathrm{dl})\end{array}$ & $\begin{array}{l}\text { HDL } \\
(\mathrm{mg} / \mathrm{dl})\end{array}$ & $\begin{array}{l}\text { LDL } \\
(\mathrm{mg} / \mathrm{dl})\end{array}$ & $\begin{array}{c}\text { Lipase } \\
(\mathrm{mol} / \mathrm{ml})\end{array}$ & $\begin{array}{l}\text { Ghrelin } \\
(\mathbf{n g} / \mathbf{m l})\end{array}$ & $\begin{array}{l}\text { FBS } \\
(\mathrm{mmol} / \mathrm{L})\end{array}$ \\
\hline $\begin{array}{l}\text { Negative } \\
\text { Control }\end{array}$ & $176.40 \pm 2.78$ & $\begin{array}{c}67.79 \pm \\
4.37\end{array}$ & $76.25 \pm 3.50$ & $2.54 \pm 0.36$ & $0.50 \pm 0.02$ & $8.40 \pm 0.23$ \\
\hline $\begin{array}{l}\text { Positive Con- } \\
\text { trol }\end{array}$ & $161.88 \pm 5.33$ & $\begin{array}{c}82.97 \pm \\
3.02\end{array}$ & $50.27 \pm 2.86$ & $2.29 \pm 0.41$ & $2.33 \pm 1.68$ & $6.34 \pm 0.27$ \\
\hline $\begin{array}{ll}200 & \mathrm{mg} / \mathrm{kg} \\
\mathrm{DB} & \end{array}$ & $154.82 \pm 5.59^{a}$ & $\begin{array}{c}69.53 \pm \\
1.20^{b}\end{array}$ & $\begin{array}{c}44.86 \pm \\
1.18^{a}\end{array}$ & $1.53 \pm 0.30^{a}$ & $\begin{array}{l}7.61 \pm \\
0.89^{a, b}\end{array}$ & $6.94 \pm 0.22^{a}$ \\
\hline $\begin{array}{ll}400 & \mathrm{mg} / \mathrm{kg} \\
\mathrm{DB} & \end{array}$ & $\begin{array}{c}139.87 \pm \\
0.76^{a, b}\end{array}$ & $\begin{array}{c}79.34 \pm \\
2.28^{a}\end{array}$ & $\begin{array}{c}33.94 \pm \\
2.64^{a, b}\end{array}$ & $1.42 \pm 0.11^{a}$ & $\begin{array}{c}10.92 \pm \\
0.18^{a, b}\end{array}$ & $6.28 \pm 0.27^{a}$ \\
\hline $\begin{array}{l}200 \mathrm{mg} / \mathrm{kg} \\
\mathrm{DB}+\mathrm{HFD}\end{array}$ & $\begin{array}{c}149.04 \pm \\
2.08^{a, b}\end{array}$ & $\begin{array}{l}69.61 \pm \\
3.01^{b}\end{array}$ & $\begin{array}{c}56.47 \pm \\
2.65^{a}\end{array}$ & $1.95 \pm 0.10$ & $\begin{array}{c}10.89 \pm \\
0.20^{a, b}\end{array}$ & $8.00 \pm 0.41^{b}$ \\
\hline $\begin{array}{l}400 \mathrm{mg} / \mathrm{kg} \\
\mathrm{DB}+\mathrm{HFD}\end{array}$ & $\begin{array}{c}143.53 \pm \\
2.58^{a, b}\end{array}$ & $\begin{array}{l}67.01 \pm \\
2.52^{b}\end{array}$ & $\begin{array}{c}43.76 \pm \\
1.92^{a}\end{array}$ & $1.89 \pm 0.31$ & $\begin{array}{l}9.47 \pm \\
0.53^{a, b}\end{array}$ & $7.08 \pm 0.45^{a}$ \\
\hline
\end{tabular}

Data are expressed as the mean \pm standard error of the mean.

a: significantly different compared to the negative control

b: significantly different compared to the positive control

$(\mathrm{p}<0.05)$. The highest percentage reduction was observed in group $5(200 \mathrm{mg} / \mathrm{kg} \mathrm{DB}+\mathrm{HFD})$, while the lowest reduction was observed in group $6(400 \mathrm{mg} / \mathrm{kg}$ $\mathrm{DB}+\mathrm{HFD})$.

The effect of Dioscorea bulbifera on the food intake of high-fat diet-induced Wistar rats is shown in Figure 1 . The data show that there was a slight increase in the food intake of the Wistar rats during the two-week treatment with extracts of Dioscorea bulbifera. However, this increase was not statistically significant ( $p>$ $0.05)$ among the groups.

\section{DISCUSSION}

Dioscorea bulbifera has been shown to possess antihyperlipidemic potentials. While the mechanism of action remains unknown, the present study evaluated the effects of hydromethanolic extract of Dioscorea bulbifera on serum lipase, ghrelin, food intake and body weight of high-fat induced obese Wistar rats. The results showed that the extract attenuated the levels of total cholesterol (TC) and low-density lipoprotein (LDL) and increased the level of high-density lipoprotein (HDL) among the experimental ani- 
Table 3: Effect of Dioscorea bulbifera on the body weight of Wistar rats

\begin{tabular}{lccc}
\hline Groups & $\begin{array}{c}\text { Weight Before the } \\
\text { Experiment }(\mathbf{g})\end{array}$ & $\begin{array}{c}\text { Weight After the } \\
\text { Experiment (g) }\end{array}$ & $\begin{array}{c}\text { Percentage Change } \\
\text { in Weight (\%) }\end{array}$ \\
\hline Negative Control & $250.40 \pm 12.23$ & $275.20^{*} \pm 13.75$ & 9.92 \\
Positive Control & $240.40 \pm 10.08$ & $230.40^{*} \pm 9.98$ & -4.17 \\
$200 \mathrm{mg} / \mathrm{kg} \mathrm{DB}$ & $244.80 \pm 5.70$ & $233.80^{*} \pm 4.48$ & -4.34 \\
$400 \mathrm{mg} / \mathrm{kg} \mathrm{DB}$ & $221.80 \pm 9.47$ & $207.40^{*} \pm 9.44$ & -4.49 \\
$200 \mathrm{mg} / \mathrm{kg} \mathrm{DB}+\mathrm{HFD}$ & $277.40 \pm 10.26$ & $261.25^{*} \pm 9.33$ & -5.82 \\
$400 \mathrm{mg} / \mathrm{kg} \mathrm{DB}+\mathrm{HFD}$ & $259.80 \pm 7.32$ & $252.20 \pm 2.51$ & -2.92 \\
\hline
\end{tabular}

Data are expressed as the mean \pm standard error of the mean.

* significantly different compared to the weight before the experiment

mals compared to the untreated control $(\mathrm{P}<0.05)$. Flavonoids, as contained in the extracts, have been shown to impact lipid metabolism by either a reduction in cholesterol synthesis or an increase in LDL receptor expression ${ }^{31,32}$. Additionally, saponins have been shown to suppress cholesterol absorption and increase lipid peroxidation ${ }^{33}$. It also acts by cholesterol secretion by depressing the rates of hepatic and intestinal cholesterol synthesis ${ }^{34}$. Previous studies have also observed an improvement in the lipid profile following the administration of extracts of Dioscorea bulbifera $^{22,28,29}$. The study also indicated a significant reduction in serum lipase among the experimental groups compared to the negative control $(\mathrm{p}<$ 0.05). Flavonoids and saponins have been reported to exhibit anti-lipase activity and ability to reduce adipocyte differentiation and lipogenesis ${ }^{35,36}$.

There was a significant reduction in fasting blood sugar among the experimental animals compared to the negative control $(\mathrm{p}<0.05)$. This glucose-lowering ability of extracts of Dioscorea bulbifera could be due to the effects of diosgenin, which is an active saponin found in Dioscorea bulbifera. Diosgenin has been shown to be an active $\alpha$-glucosidase and $\alpha$-amylase inhibitor $^{37}$. These combined actions reduce the rate of glucose absorption, thereby reducing blood glucose. Additionally, tannins, which are also present in the extract, exert their hypoglycemic action by reducing the intestinal absorption of glucose, inducing $\beta$-cell regeneration and enhancing insulin activity on adipose cells ${ }^{38,39}$.

The study also observed a significant increase in the levels of serum ghrelin in the experimental groups compared to the negative control $(\mathrm{p}<0.05)$. Ghrelin is involved in energy homeostasis, acting as a peripheral signal stimulating food intake and promoting weight gain ${ }^{40,41}$. Despite this increase in serum ghrelin, no significant change in the food intake of the experimental animals was observed compared to the negative control $(\mathrm{p}>0.05)$. This increase in serum ghrelin without a concomitant increase in food intake could be due to the inability of peripheral ghrelin to enhance food intake in obese rodents, reducing neuropeptide $\mathrm{Y}$ responsiveness to plasma ghrelin, thereby suppressing weight gain ${ }^{42}$. As expected, all the experimental animals had significantly reduced body weight after the experiment compared to their weight before the experiment $(\mathrm{P}<0.05)$. This could be due to the observed significantly reduced lipase activity, which modulates fat absorption and adipogenesis, thereby reducing body weight.

\section{CONCLUSIONS}

The study indicates that the anti-obesity potentials of hydromethanolic extracts of Dioscorea bulbifera are attributable to its ability to reduce lipase activity while attenuating lipid profile and blood glucose in high-fat obese Wistar rat models. Therefore, this study considers Dioscorea bulbifera as a potential natural antiobesity agent with possible anti-lipase activity.

\section{ABBREVIATIONS}

CVDs: cardiovascular diseases, DB: Dioscorea bulbifera, HDL: high density lipoproteins, HFD: High-fat diet, LDL: low-density lipoproteins, TC: total cholesterol

\section{ACKNOWLEDGMENTS}

None.

\section{AUTHOR'S CONTRIBUTIONS}

This study was conceptualized, designed and analyzed by BCC while PWI performed the experiment, the literature search and the preliminary draft of the article. The final manuscript was read and approved by all the authors. 


\section{FUNDING}

None.

\section{AVAILABILITY OF DATA AND MATERIALS}

Data and materials used and/or analyzed during the current study are available from the corresponding author on reasonable request.

\section{ETHICS APPROVAL AND CONSENT TO PARTICIPATE}

The study design was approved by the University of Port Harcourt Research Ethics Committee UPH/CERAMAD/REC/MM76/018.

\section{CONSENT FOR PUBLICATION}

Not applicable.

\section{COMPETING INTERESTS}

The authors declare that they have no competing interests.

\section{REFERENCES}

1. Bray GA, Tartaglia LA. Medicinal strategies in the treatment of obesity. Nature. 2000;404(6778):672-7. PMID: 10766254 Available from: 10.1038/35007544.

2. World Health Organization. World Health Organization Obesity And Overweight Fact Sheet. 2016. 2019.

3. Billington $\mathrm{CJ}$, Epstein LH, Goodwin NJ, Hill JO, Pi-Sunyer FX Rolls BJ, et al. Overweight, obesity, and health risk. Archives of Internal Medicine. 2000;160(7):898-904. PMID: 10761953. Available from: 10.1001/archinte.160.7.898.

4. Kopelman PG. Obesity as a medical problem. Nature. 2000;404(6778):635-43. PMID: 10766250. Available from: $10.1038 / 35007508$.

5. Kushner RF. Weight loss strategies for treatment of obesity. Progress in Cardiovascular Diseases. 2014;56(4):465-72. PMID: 24438739. Available from: 10.1016/j.pcad.2013.09.005.

6. Encinosa WE, Bernard DM, Steiner CA, Chen CC. Use and costs of bariatric surgery and prescription weight-loss medications. Health Affairs (Project Hope). 2005;24(4):1039-46. PMID: 16012144. Available from: 10.1377/hlthaff.24.4.1039.

7. Shekelle PG, Morton SC, Maglione M, Suttorp M, Tu W, Li Z. Pharmacological And Surgical Treatment Of Obesity: summary. AHRQ Evidence Report Summaries. 2004;103:1-22.

8. Gloy VL, Briel M, Bhatt DL, Kashyap SR, Schauer PR, Mingrone G. Bariatric surgery versus non-surgical treatment for obesity: a systematic review and meta-analysis of randomised controlled trials. BMJ (Clinical Research Ed). 2013;347(oct22 1):f5934. PMID: 24149519. Available from: 10.1136/bmj.f5934.

9. Kang JG, Park CY. Anti-Obesity Drugs: A Review about Their Effects and Safety. Diabetes \{\&amp;\}amp; Metabolism Journal. 2012;36(1):13-25. PMID: 22363917. Available from: 10.4093/ dmj.2012.36.1.13.

10. Ioannides-Demos LL, Proietto J, Tonkin AM, McNeil JJ. Safety of drug therapies used for weight loss and treatment of obesity. Drug Safety. 2006;29(4):277-302. PMID: 16569079. Available from: 10.2165/00002018-200629040-00001.

11. Marrelli M, Statti G, Conforti F. A Review of Biologically Active Natural Products from Mediterranean Wild Edible Plants: Benefits in the Treatment of Obesity and Its Related Disorders. Molecules (Basel, Switzerland). 2020;25(3):649. PMID: 32028716. Available from: 10.3390/molecules25030649.
12. Kazemipoor M, Radzi CWJWM, Cordell GA, Yaze I. Potential Of Traditional Medicinal Plants For Treating Obesity: A Review. arXiv. 2012;1208.1923:1-8.

13. Verma RK, Paraidathathu T. Herbal Medicines Used In The Traditional Indian Medicinal System As A Therapeutic Treatment Option For Overweight And Obesity Management: A Review. International Journal of Pharmacy and Pharmaceutical Sciences. 2014;6(2):40-7.

14. Moro CO, Basile G. Obesity and medicinal plants. Fitoterapia. 2000;71:73-82. PMID: 10930716. Available from: 10.1016/ S0367-326X(00)00177-5.

15. Kundu BB, Vanni K, Farheen A, Jha P, Pandey DK, Kumar V. Dioscorea Bulbifera L.(Dioscoreaceae): A Review Of Its Ethnobotany, Pharmacology And Conservation Needs. South African Journal of Botany. 2020;(In Press):1-10.

16. Lim TK. Dioscorea bulbifera. London: Springer; 2016. Available from: 10.1007/978-94-017-7276-1_10.

17. Chinelo $A E$, Regina $O A$. Comparative Analyses Of Phytochemical And Nutritional Compositions Of Four Species Of Dioscorea. Acta Scientific Nutritional Health. 2018;2(7):90-4.

18. Dutta B. Food And Medicinal Values Of Certain Species Of Dioscorea With Special Reference To Assam. Journal of Pharmacognosy and Phytochemistry. 2015;3(5):15-8.

19. Sharma LN, Bastakoti R. Ethnobotany Of Dioscorea L. With Emphasis On Food Value In Chepang Communities In Dhading District, Central Nepal. Botanica Orientalis. Journal of Plant Sciences. 2009;6:12-7.

20. Das B, Talukdar A, Choudhury MD. A Few Traditional Medicinal Plants Used As Antifertility Agents By Ethnic People Of Tripura, India. International Journal of Pharmacy and Pharmaceutical Sciences. 2014;6(3):47-53.

21. Ghosh S, Derle A, Ahire M, More P, Jagtap S, Phadatare SD. Phytochemical analysis and free radical scavenging activity of medicinal plants Gnidia glauca and Dioscorea bulbifera. PLoS One. 2013;8(12):e82529. PMID: 24367520. Available from: 10.1371/journal.pone.0082529.

22. Chinko BC, Dapper DV, Adienbo OM. Evaluation of Antihyperlipidemic Activities of Hydromethanolic Extracts of Dioscorea bulbifera. Journal of Advances in Medical and Pharmaceutical Sciences. 2020;22(1):16-25. Available from: 10.9734/jamps/ 2020/v22i130151.

23. Niyas FM. Medicinal uses of Dioscorea bulbifera-A Review. Research Journal of Pharmacy and Technology. 2015;8(8):105962. Available from: 10.5958/0974-360X.2015.00182.1.

24. Omodamiro OD. Anti-Inflammatory And Diuretic Activities Of Ethanol Extract Of Dioscorea Bulbifera Leaf. American Journal of Drug Delivery and Therapeutics. 2015;2(1):29-38.

25. Okon JE, Ofeni AA. Antidiabetic Effect Of Dioscorea Bulbifera On Alloxan Induced Diabetic Rats. CIBTech Journal of Pharmaceutical Sciences. 2013;2(1):14-5. PMID: 23432813.

26. Mbiantcha M, Kamanyi A, Teponno RB, Tapondjou AL, Watcho $P$, Nguelefack TB. Analgesic and Anti-Inflammatory Properties of Extracts from the Bulbils of Dioscorea bulbifera L. var sativa (Dioscoreaceae) in Mice and Rats. Evidence-Based Complementary and Alternative Medicine. 2011;2011:1-9. PMID: 20953397. Available from: 10.1155/2011/912935.

27. Balasubramanian J, Dhanalakshmi R, Jibnomen $P$, Manimekalai P. A Preclinical Evaluation On Antioxidant And Gastroprotective Effect Of Dioscorea Bulbifera In Wistar Rats. Indian Journal of Innovations and Developments. 2012;1(3):149-54.

28. Ahmed Z, Chishti MZ, Johri RK, Bhagat A, Gupta KK, Ram G. Antihyperglycemic And Antidyslipidemic Activity Of Aqueous Extract Of Dioscorea Bulbifera Tubers. Diabetologia Croatica. 2009;38(3):63-72.

29. Chinko BC, Dapper DV, Adienbo OM, Egwurugwu JN, Uchefuna RC. Biochemical Evaluation of the Effects of Hydromethanolic Extracts of Dioscorea bulbifera in Wistar Rats. IOSR Journal of Dental and Medical Sciences. 2016;5(9):10510.

30. Evans WC. Trease and Evans' Pharmacognosy. New York: Elsevier Health Sciences; 2009. 
31. Zeka K, Ruparelia K, Arroo RR, Budriesi R, Micucci M. Flavonoids and Their Metabolites: Prevention in Cardiovascular Diseases and Diabetes. Diseases (Basel, Switzerland). 2017;5(3):1-18. PMID: 32962323. Available from: 10.3390/ diseases5030019.

32. You CL, Su PQ, Zhou XX. [Study on effect and mechanism of scutellaria baicalensis stem-leaf total flavonoid in regulating lipid metabolism]. Zhongguo Zhongyao Zazhi. 2008;33(9):1064-6. PMID: 18652359.

33. Wang T, Choi RC, Li J, Bi CW, Ran W, Chen X. Trillin, a steroidal saponin isolated from the rhizomes of Dioscorea nipponica, exerts protective effects against hyperlipidemia and oxidative stress. Journal of Ethnopharmacology. 2012;139(1):214-20. PMID: 22100563. Available from: 10.1016/j.jep.2011.11.001.

34. Harijono $H$, Estiasih $T$, Ariestiningsih AD, Wardani NA. The Effect of Crude Diosgenin Extract from Purple and Yellow Greater Yams (Dioscorea alata L.) on the Lipid Profile of Dyslipidemia Rats. Emirates Journal of Food and Agriculture. 2016;28(7):506-12. Available from: 10.9755/ejfa.2016-01-086.

35. Yu H, Dong S, Wang L, Liu Y. The Effect Of Triterpenoid Saponins On Pancreatic Lipase In Vitro: Activity, Conformation, Kinetics, Thermodynamics And Morphology. Biochemical Engineering Journal. 2017;125:1-9. Available from: 10 1016/j.bej.2017.05.010.

36. Chantre P, Lairon D. Recent findings of green tea extract AR25 (Exolise) and its activity for the treatment of obesity. Phytomedicine. 2002;9(1):3-8. PMID: 11924761. Available from: 10.1078/0944-7113-00078.
37. Ghosh S, More P, Derle A, Patil AB, Markad P, Asok A. Diosgenin from Dioscorea bulbifera: novel hit for treatment of type II diabetes mellitus with inhibitory activity against $\alpha$-amylase and $\alpha$-glucosidase. PLoS One. 2014;9(9):e106039. PMID: 25216353. Available from: 10.1371/journal.pone.0106039.

38. Kumar A, Aswal S, Semwal RB, Chauhan A, Joshi SK, Semwal DK. Role Of Plant-Derived Alkaloids Against Diabetes And Diabetes-Related Complications: A Mechanism-Based Approach. Phytochemistry Reviews. 2019;18(5):1277-98. Available from: 10.1007/s11101-019-09648-6.

39. Ajebli M, Eddouks M. The Promising Role of Plant Tannins as Bioactive Antidiabetic Agents. Current Medicinal Chemistry. 2019;26(25):4852-84. PMID: 29874989. Available from: 10 2174/0929867325666180605124256.

40. Lv Y, Liang T, Wang G, Li Z. Ghrelin, a gastrointestinal hormone, regulates energy balance and lipid metabolism. Bioscience Reports. 2018;38(5). PMID: 30177523. Available from: 10.1042 BSR20181061.

41. Koliaki C, Liatis S, Dalamaga M, Kokkinos A. The Implication of Gut Hormones in the Regulation of Energy Homeostasis and Their Role in the Pathophysiology of Obesity. Current Obesity Reports. 2020;9(3):255-71. PMID: 32647952. Available from: 10.1007/s13679-020-00396-9.

42. Briggs DI, Enriori PJ, Lemus MB, Cowley MA, Andrews ZB. Diet-induced obesity causes ghrelin resistance in arcuate NPY/AgRP neurons. Endocrinology. 2010;151(10):4745-55 PMID: 20826561. Available from: 10.1210/en.2010-0556. 
Ready to submit your manuscript? Choose Biomedpress and benefit from:

- Fast, convenient online submission

- Through peer-review by experienced researchers

- Rapid publication on acceptance

- Free of charge (without publication fees)

Learn more http://www.biomedpress.org/journals/
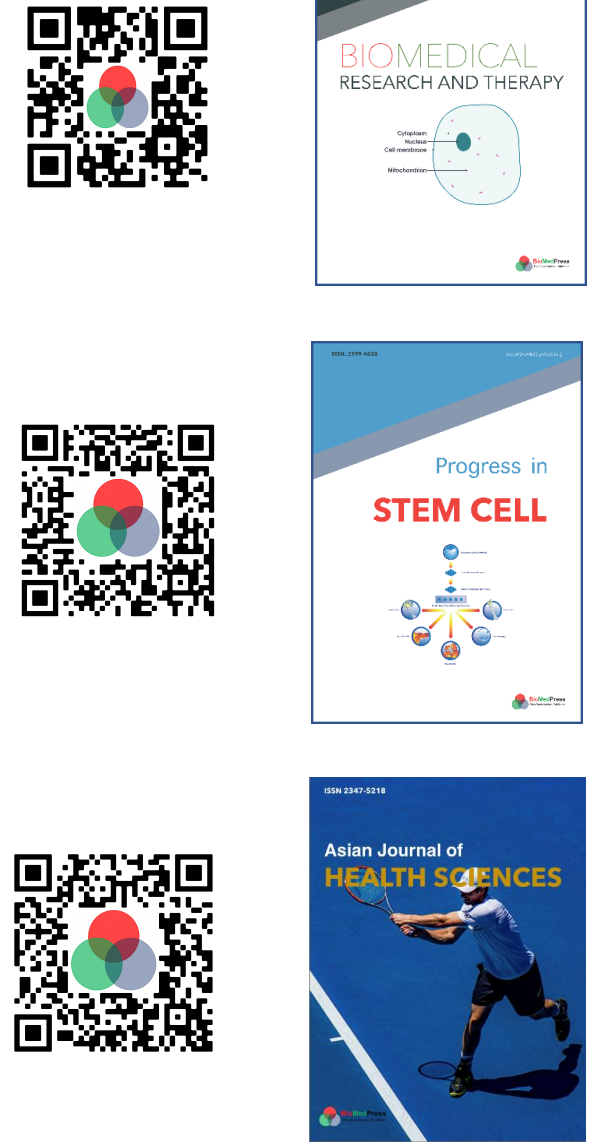

Asian Journal of Health Sciences

ISSN: 2347-5218

Indexed: Google Scholar

Acceptance Rate (2020): 72.89\%

Article Publishing Charge: Free

Submission to first editorial decision: 16.5 days

Biotechnological Research

ISSN: 2395-6763

Indexed: Google Scholar

Acceptance Rate (2020): $67.02 \%$

Article Publishing Charge: Free

Submission to first editorial decision: 28.5 days 